\title{
Supporting fathers after separation and divorce through programmatic intervention: Fortsatt Foreldre in Norway as an example
}

\begin{abstract}
This qualitative study explored the perspectives of resident and non-resident fathers on the influence of Fortsatt Foreldre in Norway, a parental intervention program that supports them in addressing concerns that come after separation or divorce. Three fathers who completed Fortsatt Foreldre were recruited to participate in an in-depth and audiotaped interview. A thematic analysis suggests that Fortsatt Foreldre is beneficial to separated/divorced fathers in many aspects, including outcomes related to fathering, child-father relationship, co-parenting, and individual psychological resilience. Interviewed fathers' narration also indicated how Fortsatt Foreldre further defines and develops the discourse of positive fatherhood within the Norwegian context.
\end{abstract}

\section{Introduction}

Compared to other European countries, Norway has comparatively higher parental separation rates, both as divorce and as dissolution of cohabiting relationships (OECD 2014). In 2014, the parents of 8,600 children in this country were divorced and those of 11,900 children were separated (Norway Statistic 2014).

A growing number of educational and/or therapeutic programs aim to help parents retain or develop a healthy parenting style after separation or divorce. Examples of such programmatic intervention in Norway include the adapted Prevention and Relationship Enhancement Program 
(PREP), ${ }^{1}$ Fortsatt Foreldre (“we are always parents"), and Godt Samliv ("good cohabitation"). ${ }^{2}$

This study focuses particularly on Fortsatt Foreldre, the continued parenting workshops, offered at Familievernkontor (Family counseling center) to parents who are separated or divorced from their partners. The aim of Fortsatt Foreldre is to facilitate the creation of parental cooperation with the ex-partner for the best interest of the children. The workshops are given over a total time scale of five weeks during which maximum ten divorced parents participate together with two workshop leaders. Workshop leaders usually encourage divorced parents from the same household to attend different workshops in order not to increase the conflict and try to enhance the intervention effects. Each week, a different theme is discussed. There are five themes in total (Bufdir 2015):

1. Separation/divorce process

2. Communication, conflict, and interaction

3. Children's living situation and their perspectives

4. Parental cooperation

5. The road ahead

Fortsatt Foreldre has been delivered to Norwegian couples for almost ten years; however, research concerning the potential influence of such program on fathers' engagement following parental separation or divorce remains rare. Moreover, minimal evidence indicates how parental interventions in general affect fathering, father-child relationships, and co-parental relationships, as well as men's psychological responses after separation or divorce (e.g. Hawkin, Amato \& King, 2007; and Kalil, Mogstad, Rege \& Votruba 2011). We therefore interviewed three fathers in Norway who had recently participated in Fortsatt Foreldre. The main purpose of this study is to explore respondents' views on the influence of the programmatic intervention they attended. Three

\footnotetext{
${ }^{1}$ PREP approach is a scientifically based and empirically tested method of teaching relationship education. It is based on more than 30 years of research in the field of relationship health, with much of the research conducted at the University of Denver, United States, and sponsored by the American National Institute of Mental Health (PREP Inc. 2015). The translated and adapted Norwegian PREP program was launched in 1998 in cooperation with original American PREP training and workshops. The program was contextualized in a Scandinavian theoretical framework in 2004 for better compatibility with Scandinavian cultures and traditions (Danielsen et al. 2012).

${ }^{2}$ Norwegian state-run program to support parents in the first year after their first child is born (Bufdit 2015).
} 
interrelated research questions are addressed in particular:

1. How does Fortsatt Foreldre influence interviewed fathers' perceptions of their role as fathers as well as the father-child and co-parenting relationships?

2. Does Fortsatt Foreldre support interviewed fathers in building their psychological resilience after separation or divorce?

3. How do participating fathers evaluate Fortsatt Foreldre with regards to their expectations and the outcomes concerning child-father and co-parenting relationships?

\section{Background}

\section{Fathers' Involvement}

Healthy fatherhood helps children thrive and develop (Burgess 2006; Heymann 2013; DeGeer, Carolo\& Minerson 2014). A substantial body of cross-cultural literature suggest that fathers' involvement exerts profound and wide-raging effects on their children's well-being throughout infancy, childhood, adolescence, and adulthood. Areas that are improved by fathers' involvement include higher cognitive development (Burgess 2006; and Newland \& Coyl 2010), increased chances of academic and economic achievements (Heymann 2013), and better mental health and social skills (Levtov et al. 2015).

The family usually comprises subsystems that affect one another. These interdependent subsystems include father-child, father-mother, mother-child, and father-mother-child relationships (Stevenson et al. 2014). The change in one relationship, such as the father-child subsystem, might influence directly and indirectly the other subsystems, such as father-mother and co-parenting. The theoretical assumption of the family system helps to explain the empirical phenomenon characterized by the observed improvement in the father-child interaction as a result of active fatherhood (Waller 2012). Furthermore, the quality of the father-child bond is significantly associated with improved couple and parents relationships (Cohen 2004; and McHale \& Irace 2011).

\section{Co-parenting}

According to the UN Convention on The Rights of the Child, children have the right to maintain personal relationships and direct contacts with both parents regularly following separation, except 
in cases where such separation is deemed to be in the best interest of the child. Cooperative parenting, based on the child rights aspect, is usually best for the children following parental separation because it focuses significantly on the need to maintain interactions with both parents as well as on the quality of coordination between adults in relation to their parental roles (Bastaits, Ponnet, \& Mortelmans 2014).

A successful co-parenting relationship requires many prerequisites that are based on the positivity of the following elements: relationship with ex-partner, personal intention and emotion, parental belief and values, and practical issues such as employment and finance (Driscoll \& Pianta 2011). In reality, a frequent barrier to successful co-parenting is when parents give in to the conflict that split them up in the first place (Poole, Speight, O’Brien, Connolly, \& Aldrich 2013). Moreover, the children's reactions toward sudden changes in their family situation might vary based on their age and temperament (Driscoll \& Pianta 2011).

\section{Norwegian Context in Separated/ Divorced Father Engagement}

In Norway, children normally reside with their mothers after parental separation, a case that is similar to those in most countries. However, in recent years, father's sole custody has increased and shared residence ${ }^{3}$ has become more common (Kitterød \& Lyngstad 2014).

Non-resident parents, mostly fathers, are expected to continue their regular contact with their children after marital dissolution. In 2003, the child allowance system was reformulated in Norway, which led to deduction of the stipulated cost of contact. In 2010, the Children Act further extended its coverage to non-resident parents' visitation rights, which directly rewards nonresident parents with extensive chances to meet with their children (Kitterød \& Lyngstad 2014).

Increasing contact between non-resident fathers and children; however, cannot guarantee active and responsible fatherly engagement, and it is also not necessarily correlated with positive children's outcomes (Kalil et al. 2011). Risk factors associated with separated/divorced people include poor relationship skills, antisocial behavior, and low socio-economic status (Poole et al.

\footnotetext{
${ }^{3}$ A significant distinction exists between joint parental responsibility and shared residence based on the Norwegian Children Act. Shared residence implies that the child lives with each parent for approximately half of the time; this situation also offers both parents equal power to decide on matters regarding the overall well-being of the children (Kitterød \& Lyngstad 2014).
} 
2013). In the case of poor parenting or relationship skills of separated/divorced fathers, proximity to such fathers might not be beneficial to the children and their overall development (Kalil et al. 2011). Furthermore, increasing direct contact without enhancement of communication skills might come at the cost of growing post-divorce conflicts among ex-spouses, or disruption of the stability in children's day-to-day lives (Maxwell 2012; and Poole et al. 2013).

Consequently, policy initiatives should focus more on supporting divorced parents to minimize the conflicts between them and the disruptions that occur during co-parenting. Fortsatt Foreldre education program, as one such Norwegian policy effort, was designed to offer tools that might help participants to sustain and improve their relationship after separation or divorce, and eventually be beneficial for their children's development (Danielsen, Ludvigsen \& Muhleisen 2012).

\section{Theoretical Framework}

\section{Family Systems Theory}

Family systems theory offers foundation for this study because it recognizes the interdependence between fathers and all other components of the family system (Cabrera, Scott, Fagan, StewardStreng \& Chen 2012). Moreover, it emphasizes that after separation, non-residential fathers are unlikely to be involved with their children unless family members continue to accept them as part of the family system (Stevenson et al. 2014). Finally, this theory identifies the importance of external social support in enabling change within families. Evidence indicates that social support is a vital resource for separated/divorced fathers in addressing stress after separation and in promoting better and healthier parental engagement with children (Waller 2012; and Cabrera et al. 2012).

\section{Psychological Resilience Theory}

Psychological resiliency is described as the capacity of individuals to effectively adapt to adversity, trauma, tragedy, threats, or other significantly stressful situations, such as family transitions and relationship break-ups, which are the focus of the present study (Schoon 2006). As existing 
empirical studies indicate, the fathers' psychological resiliency after separation/divorce is an important prerequisite of a high-quality co-parenting relationship and engagement with children (Rendall et al. 2011; and Panter-Brick et al. 2014).

\section{Methods}

\section{Study Design, Sampling, and Recruitment}

This study is qualitative and based on in-depth interviews with three separated/divorced fathers (both residential and non-residential). The University of Stavanger and the Norwegian Social Science Data Services (NSD) approved all the study's procedures. Data were collected from February 2015 to April 2015.

The purposive sampling technique was applied using the following sample selection criteria: 1) men who have completed Fortsatt Foreldre workshops in Stavanger, Rogland, Norway; 2) participants are at least 18 years old and had at least one child aged 18 years or younger; and 3) participants are willing and confident to communicate in English.

In April 2014, the authors contacted the leader at Familievernkontor Stavanger and acquired consent to recruit participants based on the sample selection criteria. With significant support from the psychologists who lead Fortsatt Foreldre, the authors obtained a list containing the names and contact information of the fathers who agreed to engage in the study. In January 2015, the authors made the initial phone calls or emails to each potential participant to confirm interview time and location based on the respondents' preference. Eventually, the interviews with three fathers were arranged; two were conducted at the counseling center itself, whereas one was held at the respondent's home.

Table 1: Profile of the Participants

\begin{tabular}{llllll}
\hline Name & Age & $\begin{array}{l}\text { Custodial } \\
\text { Status }\end{array}$ & $\begin{array}{l}\text { Highest } \\
\text { Level of } \\
\text { Education }\end{array}$ & $\begin{array}{l}\text { Number } \\
\text { of } \\
\text { Children }\end{array}$ & $\begin{array}{l}\text { Ages of } \\
\text { Children }\end{array}$ \\
\hline
\end{tabular}




\begin{tabular}{cccccc} 
Karl & 41 & $\begin{array}{c}\text { Non- } \\
\text { residential }\end{array}$ & High school & 2 & 12 and 10 \\
Johan & 38 & $\begin{array}{c}\text { Non- } \\
\text { residential }\end{array}$ & High school & 3 & 11,10 , and 7 \\
Alexander & 46 & Residential & $\begin{array}{c}\text { Graduate } \\
\text { school }\end{array}$ & 3 & 17,13 , and 9 \\
\hline
\end{tabular}

Formulated by the authors

\section{Data Collection and Analysis}

Data were collected using open-ended, in-depth interviews. The final version of the interview guide includes three sections: 1) fathers' motivations, expectations, and process of participation in Fortsatt Foreldre workshops; 2) perceived changes in parenting, father-child relationship, and coparenting after workshops; and 3) fathers' perceptions concerning the influence of co-parenting workshops.

Prior to respondents' participation, the researchers read the informed consent form to them. Participant fathers were requested to sign the form after they gained clear understanding of their roles and rights during the time of the study. Each interview in this project lasted approximately one hour and was audio recorded with the respondents' permission.

The formal data analysis started once all the transcripts were available. The entire analysis process included five stages: categorization (using coding to identify concepts), condensation (looking for possible themes), narrative structuring (forming and restructuring stories), deeper interpretations (generating meaning of stories through multiple approaches), and formulation of final themes related to research questions (Kvale 1996).

\section{Ethical Consideration}

The researchers applied three main strategies to secure the ethical features of this study: 1) obtaining authorization from NSD to conduct the project that involves direct contact with human 
beings; 2) ensuring that all participants were fully aware of the purpose, methods, possible risks, and potential uses of the study by requesting them to review and then sign the informed consent form; and 3) preserving and respecting respondents' confidentiality and anonymity by using pseudonyms instead of real names, removing all detailed information (e.g., respondents' workplaces) that could provide a link to the participants' identity, and storing collected data in a secure location.

\section{Findings}

\section{Positive Attitudes towards Fathering Roles}

The three fathers in this study generally displayed positive attitudes and intentions toward their children and their role as fathers. Below is a story told by one of the fathers concerning how Fortsatt Foreldre progressively helped him to realize the importance of putting aside any conflict with, or negative feeling toward, his expartner to enable him to focus on his children's best interests and satisfy their needs.

My ex-wife is too protective and she then thinks I am too relaxing and careless about our kids. She sometimes thought she was better than me in taking care of our children and she started pushing me away from doing things with the kids.

Now (after divorce), I am glad that I eventually could spend more time with my children alone when they are at my place. I can do what I want with them. But when she had the kids, she used to just disappear with them. I had no clue where they were and what they were doing. She never told me anything. We started to fight about this in the beginning.

My intention for trying this course in the first place was to be able to communicate better with my ex-wife so we could both work on our children. I want to learn at least how other people see the situation (the separation), and how their communication with 
their ex-partners became better. After a while (of the course), I realized that conflicts between us might influence our kids badly, so I finally gave up. I need to be more positive with our relationship even though it is not always easy to do so. (Karl)

Another outcome of Fortsatt Foreldre, as Alexander reported, was the reduction in conflicts related to children's discipline. According to this father, the model of his parental practices changed from a deficient and critical model to a more understanding one whose main aim is to cooperate with the child to solve problems more efficiently.

My eldest boy is a kind of happy, lucky, and an easy-going person. He hardly ever takes things too seriously. When he was 15 , we thought that he should be responsible for his own daily life, so we required of him to set an alarm and get up in the morning earlier by himself. If I woke up and found him still asleep, I became really angry and started judging him. The situation did not get better after my criticism. He still continued to get up late, and I felt very irritated due to his behavior. I used to consider him as the one who was always breaking the rules. When I was preparing for the course, I started thinking how my son perceives me as a father. The first thing he hears every morning is me not yelling but criticizing him. I think nobody looks forward to starting a day with such a bad emotion, and to be reminded that you are failing in something you are actually trying to achieve. I should offer more support instead of doing nothing but judge.

\section{Positive Intentions and Increased Skills in Co-parenting}

The importance of both parents working actively together for their children's best interest is another recurrent theme in this study. The three interviewed fathers expressed the intention to have an efficient relationship with their ex-partner to ensure that their children will be provided a healthy and consistent childhood. However, the three fathers also pointed out that their current relationships with their ex-spouses were generally poor. 
(After workshops) I was left with a lot to think about but I don't think our relationship changed so much. People in the course talked about the child having such and such problems. But the problems of the child are the symptoms of the problems of the mother and the father. We should work on ourselves first before we start blaming the children. (Johan)

When I brought the kids back to her (the ex-wife), she did not speak very much even though I really wanted to talk. Our relationship is really complicated and I know it is difficult to turn things around...Before the divorce, we had a big house, not this one. When our relationship turned bad, I moved out and lived in the basement while she lived in the house. I spent four and half years there, in the basement, such a long time, a really hard period. The divorce itself is better, both for me and the children, but she tried very hard to keep them away from me. I don't think I deserve that, and everyone who knows us will agree on this. She has a bad opinion of me, like I cannot be a good father. It is a challenge to change her perception of me, and it is hard to let her believe I could also take care of the children well enough. (Karl)

Despite the strained relationships, two fathers emphasized that their perceptions toward their ex-spouses gradually shifted during the workshops. Specifically, they tended to become more empathetic and understanding of their ex-partners' behaviors. Additionally, they began to focus on their issues and to manage their emotions rather than criticizing those of others.

Have to admit that it was not easy for her (the ex-wife) to face the divorce or trust men in general. Her father left her and her mother suddenly when she was young. He visited a brother who was marrying someone in Thailand. He came back home four months later. Not so many days after, he said that he has to pick someone up from the airport, and then he just left and totally disappeared. Now he lives in Thailand and has two children there. I don't know if my ex-wife thought that I would be like her father. This might be a reason that makes her crazy and difficult to have trust in our relationship. 
(Karl)

She has the right to be upset, but instead of blaming her for what she did, I think I should just focus on how I feel and how I perceive her behavior. People could only change themselves, right? Sometimes I felt emotionally triggered in our relationship, and I didn't do the right thing, in which case, I should have taken two steps back and evaluated why I was triggered instead of judging her for what she had done. As a therapist, I should be able to analyze my own feelings, why this made me upset, why it was important to me and what I could have done or should I have done something different. (Alexander)

Moreover, interviewed fathers admitted that, to different extents, they acquired certain communication or conflict management skills. These newly learned skills could be, in the future, a foundation for an effective co-parenting relationship. For example, Karl learned from the stories of other participants in the workshops that having a positive attitude and behavior is the first step toward better communication with his ex-wife.

Likewise, Alexander realized that he and his ex-wife play equally important roles in their children's lives. The couple must "agree that sometimes they could disagree on some things." Additionally, it would be inefficient and unwise to engage in gate-keeping behaviors, to force the child to choose sides among the parents, and to opt for a negative tone when talking to the child about his or her mother.

The courses indeed helped me to accept that me and my ex-wife have both very important parts in our daughter's life. My daughter is nine years old, the youngest one in the family, and of course she was treated as a princess. I had an idea that a fatherdaughter relationship should be special. I have two sons and the relationship with them is extremely good, so I was expecting I will get such strong connection with my daughter as well.

But after the divorce, my daughter apparently developed a better relation with her 
mother. The bonding between them is exceptional. If I need to put a number on that, I would say that the mother occupies $80 \%$ of my daughter's daily life while I occupy only $20 \%$. I know I have to accept this, because in reality, I don't paint my nails, have long hair, make a pony tail, and I cannot do girly things like her mother does with her. I have tried. I remember once I invited her to go out and shop with me, like she does with her mother. She just looked at me and laughed, saying that men do not go shopping. The parenting course, in some way helped me cope with my disappointment about our relation. I should be glad that our daughter is closer to her mother. I am a bit envious but I do not want to complain anymore or do anything to interfere with their relationship. (Alexander)

\section{Psychological Resilience}

Common psychological responses to the end of a relationship are pain, anger, frustration, helplessness, and even depression. As Karl mentioned in the interview, after the divorce he was "very depressed, and just wanted to lay there and do nothing". Additionally, all interviewed fathers expressed their fear of losing contact with their children, which added to their stress. For example, Karl complained that he only received $21 \%$ of custody of his children after the divorce, which he perceives as a treat to his relationship with his children. Alexander uncovered his pain when he mentioned that his ex-wife participates in $80 \%$ of his daughter's life while he only contributes in the remaining $20 \%$.

Despite of frustrated or even depressive psychological response to the end of the marital relationship, fathers in the interviews indicated that the Fortsatt Foreldre workshops indeed helped them drop their guard, liberated them from the feelings related to divorce and separation, and enabled them to better vent negative emotions.

One night at the beginning of the course we saw a movie. There was a couple, you saw how they started their relationship. They had a child, then they separated. They were invited to the same party. They had the same friends, and it was not easy to just invite one of them. After that movie we talked about our own experience. I remembered I was 
talking very much that day.

At beginning it was so hard. Some things always make it difficult to talk in front of others. But, there is confidentiality in that room, making us more relaxed in sharing our thoughts and feelings. I think I had a very good connection with everyone in the room. We finally talked openly and discussed a lot. I felt kind of released, by telling others my emotions and listening to others' stories. There was a guy who talked about how his exwife expected crazy things from him and how he reacted in a very bad way. I felt lucky in some way that I didn’t at least go through such craziness. (Karl)

An essential part of Fortsatt Foreldre is to encourage participants to share their feelings on marital dissolution and to discuss the underlying meanings of emotions. Karl's declaration above suggests that by reflecting, sharing, and discussing with parents in similar situations, he benefited from the possible venting of his negative emotions, which is considered the start of psychological resilience (Waugh \& Koster 2015). Beyond this, gaining a clear view of the present situation, learning from others, and realizing one's own strengths are positive outcomes perceived by the participating fathers.

You can see the problem and talk about it (in the course). It then makes the problem clearer...I know I had a strong reaction (concerning divorce) but I did not see the strength of my reaction. Now, it was easier to see my strength in other people's reactions. (Johan)

I think I did reflect a lot before, but now (after Fortsatt Foreldre) I reflect even more. I allowed myself more time to think about situations in different ways. In this course, you could easily see things through others, who talked about their conflicts and stories. You see how people can easily make a tiny problem become a serious one and how people focus on others' faults rather than their own. You will then start examining yourself to see how many stupid things you have done to make the situation worse, or what efforts you could do now to make things better. (Alexander) 
The three fathers in this study expressed appreciation for opportunities to share their stories with others, deconstruct their hardness, and/or achieve a new view toward different situations or problems. However, the interviews do not offer sufficient evidence that would indicate improvement in the fathers' confidence and identity as an outcome of Fortsatt Foreldre. The fathers reported a greater sense of "being heard," "feeling supported," and a greater ability to "see things through" more clearly (Karl, Johan, and Alexander), which could indicate improved psychological well-being and adjustment to separation or divorce.

\section{Fathers' Evaluation of Fortsatt Foreldre Program}

"All about the children" is the essential slogan that Fortsatt Foreldre uses to initially attract participants. However, only one of five program sessions is specifically devoted to children's issues. In that one session, topics such as how to enhance parent-child communication and how to help children adjust after parental divorce are discussed. Johan mentioned in the interview that he was disappointed by the course arrangement because his initial motivation to participate was to share his experience regarding children's problems after divorce with others.

In fact, as indicated in the introduction booklet of Fortsatt Foreldre, the aim of the co-parenting workshops is to enhance parents' collaboration for the benefit of children (Fortsatt Foreldre 2015). In other words, Fortsatt Foreldre has its own principle, that is, to support efficient co-parenting behavior for the best interest of the children. However, Johan had expected something else than what he received. This might imply a communication issue between Fortsatt Foreldre professionals and clients - the former did not help the latter to clearly understand the principle and goals of the workshops and/or the dynamics of such intervention programs.

In addition to recruiting and retaining fathers in the program, consulting the participants regarding their goals for participation is necessary as well as tailoring the curriculum accordingly. Otherwise, as the two fathers stated, Fortsatt Foreldre faces the challenge of addressing their individual demands. 
The course should devote more time for discussion about children. A lot of the courses address the break-up situation. So, each time you expect something different. I have been attending other individual counseling services by Stavanger familievenkotoret, and they are more beneficial for me than this one. (Johan)

I think the hardest part is when you notice that one of the participants is more in need of individual therapy than of group participation. You can see the conflict in which he is still in; he is really serious and that tries to get some answers but those answers are within himself. He had just broken up, and was still in disarray. He could not control himself well emotionally or behavior wise. He had to at least stand up for his own grief. His condition simply could not support him enough to achieve something from this course. (Alexander)

\section{Discussion}

\section{Fortsatt Foreldre's Role in Supporting Selected Fathers}

The current research findings support existing evidence indicating the important role of social support in helping separated/divorced fathers to decouple from former intimate relationships with their ex-spouses and to build new co-parenting systems for the best interest of the children (e.g. Waller 2012; and Cabrera et al. 2012). Fortsatt Foreldre, from our respondents' views, offers resources and information for selected fathers in addressing stress after separation and in promoting better and healthier parental engagement with children.

Specifically, as our findings suggest, Fortsatt Foreldre workshops built selected fathers' psychological resilience after separation or divorce. As previous studies have indicated, psychological well-being is the essential foundation to emotional de-coupling and further coparenting (Rendall et al. 2011; Panter-Brick et al. 2014; and Waugh \& Koster 2015). Different 
factors could promote resilience, and Fortsatt Foreldre focuses on those following: selected fathers' ability to manage strong negative psychological feelings and impulses after separation or divorce, their capacity to make realistic plans and take steps to implement them, positive viewpoints towards themselves and their personal strengths and abilities, and skills in communication and problem solving (e.g. Fagan et al. 2009; and Waugh \& Koster 2015).

Building a new and healthy co-parenting system is a challenging undertaking. Interviewed fathers are unlikely to be involved with their children's lives unless the mothers accept them as a part of the family system. For example, Karl complained that his ex-wife "was trying to keep the children away from him" and that she believes that "she is good enough to take care of the children by herself."

Our findings indicate that Fortsatt Foreldre exerted positive influences on certain elements which are considered as prerequisites for successful co-parenting. Those elements include: selected fathers' positive attitudes towards their role as fathers; a communicative relationship with children and ex-partners; and skills and techniques to manage conflict and conduct efficient communication (e.g. Driscoll \& P ianta 2011; and Poole et al. 2013). Furthermore, Forsatt Foreldre workshops support fathers' co-parenting by promoting public perceptions which emphasize that fathers are as equally good care givers as mothers.

Fathers' evaluation of Fortsatt Foreldre suggests that co-parenting is a process that is associated with the nature of the relationship dynamics that were established before marital dissolution (Coates \& Phares 2013). The types and content of intervention programs, therefore, have to distinguish between parents who reside on different positions of the relationship continuum (Coates \& Phares 2013). For highly conflicted parents, such as Karl in this study, a course focusing on successful de-coupling and negotiation of conflict might be more beneficial than a co-parenting workshop. For parents who are less harmonious but are willing to and able to cooperate for the sake of the children, such as Alexander, Fortsatt Foreldre is more advantageous because it addresses the strengthening of the co-parental relationship.

\section{Authors' Reflection on Fortsatt Foreldre}

This research addresses a co-parental program in Norway and all interviewed respondents are 
Norwegian. The experience of fatherhood discussed in this article reflects values and beliefs shared by the Norwegian society, or broadly Scandinavian societies. Furthermore, culture actually patterns experiences of persons on the basis of their gender. In other words, public discourses concerning 'a good father' varies dramatically across cultures. Expectations and beliefs concerning gender and parenting are continuously defined by historical, economical, and political changes as well as religious beliefs in the society.

Norway, as other Scandinavian welfare states, pioneered the transformation of parenthood into political issues. From as early as 1970s, gender equality has been a crucial part of the Scandinavian citizenship regime. The politicization of parenthood and gender equality were strongly connected. In particular, the care of children has been central to the promotion of gender equality in the propose of enhancing opportunities for working mothers and caring fathers (Ellingsæter \& Leira 2006).

As stated in the background chapter, Norway has continuously adjusted politics according to the women's role in society and welfare-state intervention in family arrangements. Parental responsibility has been gradually translated into individual rights of both mothers and fathers. Although there are still gendered images towards 'good mother' and 'good father', a larger number of individuals accept fathers as competitive caretakers (Kitterød \& Lyngstad 2014).

Looking at fatherhood from a socio-cultural perspective is important because it helps us broaden conceptual thinking about fathers. Both authors of this article come from different cultural backgrounds. One author is a Chinese woman and she comes from a society where Confucian teachings about patriarchy and intergenerational hierarchies in family structures are among the essential principles of social organization. The traditional values such as "strict fathers" and "kind mothers" clearly still dominate into current modern society where the author was born. Most men in that society tend to keep distance with their children during their growing up in order to build a "tough father" image. Moreover, grandparents and domestic helpers play much greater roles in child rearing in most Chinese families. The involvement of these members could exert varying effects on father-mother and father-child relationship.

The other author is a Lebanese woman and she perceives that "doing the family" in Lebanon depends highly on the social class of that family. For example, in the case of wealthy Lebanese families, the au pairs might become more involved in the children's lives than their fathers. The 
patriarchal society tendencies, men taking at heart their roles as breadwinners while women taking charge of child rearing, are more practiced by working class families. In fact, family practices in Lebanon have been changing quite fast as the cost of living has been increasing and it has become difficult for men to carry the burden of financing their families' lives on their own. Women are more and more included in the job market, especially the ones getting higher education. However, more often than not, women end up carrying more than they can handle between their full-times jobs and their mothering duties as well as the house choirs.

Fortsatt Foreldre is an initiative undertaken by the Norwegian government and is viewed by the authors of this article as helpful in regards to strengthening father-child relationship after parental separation or divorce. Fortsatt Foreldre highlights and advocates men's responsibilities and rights to participate in their children's lives. Fathers play an equally important role as mothers do. All Norwegian fathers in this research valued fatherhood as a pleasant experience and they also experienced psychological strain when they had a negative father-child and co-parental relationship. From the psychological resilience perspective, Fortsatt Foreldre focuses on enhancing participants' ability to manage strong negative feelings and impulses and to make realistic plans and take steps to implement good co-parenting.

\section{Conclusion}

This research explored views of three Norwegian separated or divorced fathers in regards to Fortsatt Foreldre, a programmatic co-parenting program they had recently attended. Our findings suggest those participants generally have a positive attitude towards their roles as fathers. Fortsatt Foreldre workshops increased those individuals' psychological strengths and practical capacity in dealing with their father-child and co-parenting relationships; although achieving positive and effective communication with ex-partners is still a significant challenge faced by all interviewees. The fathers' evaluation of Fortsatt Foreldre suggests that intervention programs should distinguish among parents with different kinds of relationships with their ex-partners. For highly conflicted parents, the efforts might better be allocated to de-coupling and negotiation of conflicts instead of co-parenting. In the authors' perception, the findings of this research also describe the way in which Fortsatt Foreldre operates to strengthen a public image about fathers as competitive caregivers in the Norwegian context. 
The main limitation of this research is the fairly small sample size, which limits its representativeness; thus, the findings cannot be generalized to the wider population. The small sample size precluded the identification of subtle differences within the whole group of Fortsatt Foreldre participants. Therefore, future studies involving larger and more demographically diverse samples are needed for drawing a broader conclusion. In addition, being full-time students studying social work with previous work experience with families, it is unavoidable for the authors not to carry some prejudgment while designing the investigation, and later processing the findings of the study. Therefore, future studies should be conducted by scholars with diverse backgrounds.

\section{Reference}

Bastaits, K., Ponnet, K. \& Mortelmans, D. (2014). Do divorced fathers matter? The impact of parenting styles of divorced fathers on the well-being of the child. Journal of Divorce \& Remarriage. 55,363-390.

Burgess, A. (2006). The Costs and Benefits of Active Fatherhood: Evidence and Insights to Inform the Development of Policy and Practice, London, UK; Fathers Direct.

Bufdir (2015). Kurstilbudet Fortsatt Foreldre - for godt nok foreldresamarbeid, retrieved from http://www.bufdir.no/Familie/Mekling_samlivsbrudd/Mekling/Kurstilbud_Fortsatt_foreldre /

Cabrera, N.J., Scott, M. E., Fagan, J., Steward-Streng, N., \& Chen, N. (2012). Co-parenting in married and cohabiting families and children's school readiness: A mediational model, Family Process, 51, 307-324.

Coates, E. E., \& Phares, V. (2013). Predictors of paternal involvement among nonresidential, black fathers from low-income neighborhoods, Psychology Of Men \& Masculinity, 15, 138-151.

Cohen, S. (2004). Social relationships and health. American Psychologist, 59, 676-684.

Danielsen, H., Ludvigsen, K.\& Muhleisen, W. (2012). Governing couple-sexuality: publically funded couples' courses in Norway. Culture, Health \& Sexuality, 14, 645-658.

DeGeer, I., Carolo, H.\& Minerson, T. (2014). Give Love, Get Love: The Involved Fatherhood and 
Gender Equality Project, Toronto, ON: White Ribbon Campaign.

Driscoll, K., \& Pianta, R. C. (2011). Mothers' and fathers' perceptions of conflict and closeness in parent-child relationships during early childhood, Journal of Early Childhood and Infant Psychology, 7, 1-24.

Fagan, J., Palkovitz, R., Roy, K., \& Farrie, D. (2009). Pathways to paternal engagement: Longitudinal effects of risk and resilience on nonresident fathers. Developmental Psychology, 45,1389-1405.

Hawkin, D. N., Amato, P. R. \& King, V. (2007). Nonresident father involvement and adolescent wellbeing: father effects or child effects? American Sociological Review, 6, 990.

Helskog, G. H. (2009). The Norwegian State: A Relationship Educator, What Works in Relationship Education? retrieved from http://www.relationshipeducation.info/downloads/pdf/11\%20Helskog.pdf.

Hemminki, K. \& Li, X. J. (2003), Lifestyle and cancer: effect of widowhood and divorce, Cancer Epidemiology Biomarkers and Prevention, 12(9), 899-904.

Heymann, J. (2013). Children's Chances: How Countries Can Move from Surviving to Thriving, Cabridge, M.A.: Harvard University Press.

Levtov, R., van der Gaag N, Greene, M., Kaufman, M. \& Barker, G. (2015). State of the World's Fathers, A MenCare Advocacy Publication, Washington.

Jurma, A. M. (2015). Impact of divorce and mother's physiological well-being on children's emotional, behavioral and social competences, Working Together, 48, 69-82.

Kain, K. , Ide, N. \& de Leo, D. (2010), Suicidal ideation and behavior in the aftermath of marital separation: gender differences, Journal of Affective Disorder, 120(1-3), 48-53.

Kalil, A., Mogstad, M., Rege, M. \& Votruba, M. (2011). Divorced fathers' proximity and children's long run outcomes: evidence from Norwegian Registry Data, Demography, 48(3), 1005-1027.

Kitterød, R. H. \& Lyngstad, J. (2014). Characteristics of parents with shared residence and father sole custody, evidence from Norway 2012, Statistics Norway Research Department, 780.

Maxwell, N. (2012). Engaging fathers in child welfare services: a narrative review of recent 
research evidence, Child and Family Social Work, 17(2), 160-169.

McHale, J., \& Irace, K. (2011). Co-parenting in diverse family systems. In J. McHale \& K. M. Lindahl (Eds.), Co-parenting: A Conceptual and Clinical Examination of Family Systems, Washington DC: American Psychological Association, 15-38.

Newland, L. A. \& Coyl-Shepherd, D. C. (2010). Father's role as attachment figures: An interview with Sir Richard Bowlby, Early Child Development and Care, 180(1-2), 25-32.

OECD (2014). Marriage and Divorce Rates, retrieved from http://www.oecd.org/els/family/SF3_1_Marriage_and_divorce_rate_Jan2014.pdf .

Panter-Brick, C. Burgess, A. Eggerman, M. McAllister, F. Pruett, K. \& Leckman, J. F. (2014) Practitioner review: engaging fathers- recommendations for a game change in parenting interventions based on a systematic review of the global evidence, Journal of Child Psychology and Psychiatry, 55(11), 1187-1212.

Poole, E., Speight, S. O'Brien, M. Connolly, S. \& Aldrich, M. (2013). Fatherhood in the UK: What do we know about non-resident father, Modern Fatherhood, retrieved from http://www.modernfatherhood.org/wp-content/uploads/2013/11/Briefing-paper-Nonresident-fathers.pdf.

Reczek, C. \& Umberson, D. (2012) Gender, health behavior, and intimate relationship: lesbian, gay, and straight contexts, Social Science and Medicine, 71(11), 1783-1790.

Rendall, M. S., Weden, M. M., Waldron, H. \& Favreault, M (2011), The protective effect of marriage for survival: A review and update, Demography, 48(2), 481-506.

Schoon I. (2006). Risk and Resilience. Adaptations in changing times. Cambridge, Cambridge University Press.

Statistics Norway (2014), Marriage and Divorces, retrieved from https://www.ssb.no/en/ekteskap/ [Retrieved on $15^{\text {th }}$ Nov 2015

Stevenson, M. M., Fabricius, W. V., Cookston, J. T., Parke, R. D., Coltrane, S., Braver, S. L., \& Saenz, D. S. (2014). Marital problems, maternal gatekeeping attitudes, and father-child relationships in adolescence. Developmental Psychology, 50(4), 1208-1218. 
Waller, M. R. (2012). Cooperation, conflict, or disengagement? Co-parenting styles and father involvement in fragile families, Family Process, 51(3), 325-342.

Waugh, C. E., \& Koster, E. H. W. (2015). A resilience framework for promoting stable remission from depression, Clinical Psychology Review, 41,49-60. 